\title{
PERSPECTIVE
}

\section{Hand washing agents and surface disinfectants in times of Coronavirus (COVID-19) outbreak}

Abhilasha Kapoor ${ }^{1}$, Rumpa Saha²

${ }^{1}$ Postgraduate Student, Department of Community Medicine, University College of Medical Sciences \& GTB Hospital, Delhi; ${ }^{2}$ Professor, Department of Microbiology, University College of Medical Sciences \& GTB Hospital, Delhi

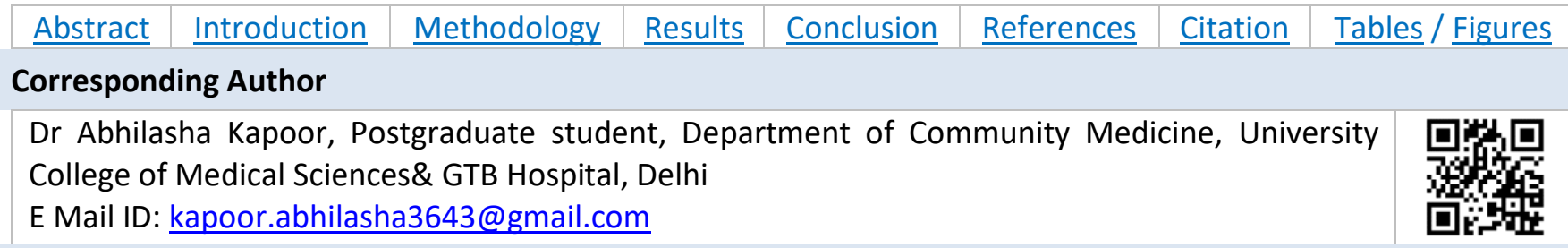

\section{Citation}

Kapoor A, Saha R. Hand washing agents and surface disinfectants in times of Coronavirus (COVID-19) outbreak. Indian J Comm Health. 2020;32(2-Special Issue):225-227.

Source of Funding: Nil Conflict of Interest: None declared

\section{Article Cycle}

Received: 10/04/2020; Revision: 14/04/2020; Accepted: 15/04/2020; Published: 20/04/2020

This work is licensed under a Creative Commons Attribution 4.0 International License.

\section{Abstract}

Coronavirus pandemic has led to thousands of cases and hundreds of deaths worldwide. India, too, is on the verge of this health risk at the national scale. The only measures to prevent this pandemic from spreading are physical distancing, hand hygiene, and surface disinfection, and wearing of appropriate masks. Many hand sanitizers and surface cleaning agents are being made available which are being claimed to be virucidal and to be effective against coronavirus. Here, we present a review of the hand washing agents and surface disinfectants which have virudical properties and are effective against coronaviruses. This review will help dispel misconceptions about various hand washing agents and surface disinfectants and also help to make informed decisions regarding these items.

\section{Keywords}

Handwashing; Disinfectants; Coronavirus; Virucidal

COVID-19 is a respiratory viral infection and can spread from person to person through small droplets from the nose or mouth which are spread when an infected person coughs or exhales. These droplets land on objects and surfaces around the person. Other people contract COVID-19 by touching these objects or surfaces, then touching their eyes, nose, or mouth. People can also get COVID-19 if they breathe in droplets from a person with COVID-19 who coughs out or exhales droplets. Enhanced hygiene including wearing face masks and most importantly keeping the hands clean are the firsthand measures against spread of respiratory viral infections. (1)

Coronaviruses are enveloped viruses which makes it susceptible to appropriate lipid solvent disinfectants.
We will discuss in the following sections about the role of various antiseptics and disinfectants including soap and water, alcohol-based hand-rubs, chlorine solutions and others in reducing the transmission of viral infections. A review has shown that human corona viruses survive on surfaces for a period ranging from 2 hours to 9 days. (2) Various agents present virucidal activities and help to reduce the transmission of viral infections. A list of hand washing agents and surface disinfectants that are effective against coronaviruses, are described for ready reference during these times of COVID-19 outbreak. These descriptions are meant for health care workers in hospital-based settings. 
Soap and water: If hands are visibly dirty, they should be washed with soap and water for 40-60 seconds using the appropriate hand washing technique. (3) Machine washing of the linens with warm water $60-90^{\circ} \mathrm{C}\left(140-190^{\circ} \mathrm{F}\right)$ with laundry detergent is recommended. If machine washing is not possible, linens can be soaked in hot water and soap in a large drum using a stick to stir but being careful to avoid splashing. The drum then should be emptied, and the linens should be soaked in $0.05 \%$ chlorine for approximately 30 minutes. Finally, the laundry should be rinsed with clean water and the linens should be allowed to dry fully in sunlight. (4)

Alcohol-based preparations: If hands are not visibly dirty, the preferred method is to perform hand hygiene with an alcohol based hand rub for 20-30 seconds using appropriate technique.(4) The World Health Organization (WHO) recommended formulations for hand washing contain either $75 \%$ $\mathrm{v} / \mathrm{v}$ isopropanol or $80 \% \mathrm{v} / \mathrm{v}$ ethanol. (3) Alcohol based hand rubs, hand sanitizers containing $60-90 \%$ of ethyl alcohol or isopropyl alcohol solutions in water can be used for cleaning of hands and as surface disinfectants as they are potent virucidal agents inactivating all the lipophillic viruses. (5) A review by Kampf $\mathrm{G}$ et al reported that $62-71 \%$ ethanol as surface disinfectant, can efficiently inactivate human coronaviruses such as Severe Acute Respiratory Syndrome (SARS) coronavirus, Middle East Respiratory Syndrome (MERS) coronavirus or endemic human coronaviruses ( $\mathrm{HCoV}$ ) within 1 minute. (3) WHO recommends $70 \%$ ethyl alcohol to disinfect small areas between uses. (4)

Chlorine solutions: When an alcohol-based hand-rub and soap are not available, then chlorinated water $(0.05 \%)$ can be used for hand washing. However, using chlorinated water for hand washing is not ideal as it may lead to dermatitis because prepared dilutions might be inaccurate. (4) Kampf $G$ et al reported that $0.1 \%$ sodium hypochlorite solution as surface disinfectant, can efficiently inactivate human coronaviruses within 1 minute. (2) WHO recommends sodium hypochlorite at $0.5 \%$ (equivalent to $5000 \mathrm{ppm}$ ) for disinfecting surfaces. (4) Household bleach is a solution of sodium hypochlorite which generally contains $5 \%$ ( $50 \mathrm{~g} /$ litre) of available chlorine. To prepare a $0.5 \%$ solution, one volume of sodium hypochlorite (one litre) is to be mixed with nine volumes of water (nine liter). Bleaching powder (chlorine of lime) consists of $30 \%$ active chlorine. $16 \mathrm{gm}$ or one tablespoon in one liter of water prepares 1:10 bleach solution containing $0.5 \%$ of chlorine solution.

Chlorhexidine containing formulations: Chlorhexidine in a concentration of $0.5-4 \%$ can be used for hand washing to reduce the infectivity of enveloped viruses. (2) Review done by Kampf G et al reported that $0.02 \%$ chlorhexidine digluconate as surface disinfectant, can inactivate human coronaviruses but less efficiently as compared to alcohol-based preparations and chlorine solutions. (2) Chlorhexidine demonstrated inactivating effect on enveloped viruses (HSV type I, HIV type I) but was ineffective against enveloped human coronavirus and non-enveloped viruses. (6)

lodine or lodophors: Various commercially available formulations of Povidone lodine have effective virucidal activities. For example, $7.5 \%$ povidone iodine surgical scrub, soap containing povidone iodine for hand washing. lodophors in a concentration of $0.5-10 \%$ can be used for hand washing to reduce the infectivity of enveloped viruses. (2)

Hydrogen peroxide: $0.5 \%$ accelerated Hydrogen Peroxide in 1 minute has virucidal activity as surface disinfectant. Kampf $\mathrm{G}$ et al reported that $0.5 \%$ hydrogen peroxide within 1 minute was effective in reducing the infectivity of human coronaviruses. (2) (Table 1).

\section{Authors Contribution}

All authors have contributed equally.

\section{References}

1. World Health Organization. Q\&A on coronaviruses (COVID-19). WHO/Newsroom 2020. Available from: https://www.who.int/news-room/q-a-detail/q-acoronaviruses [Accessed on 2020, April 3rd].

2. Kampf G, Todt D, Pfaender S, Steinman E. Persistence of coronaviruses on inanimate surfaces and their inactivation with biocidal agents. J Hosp Infect 2020;104(3):246-51.

3. World Health Organization. WHO guidelines on hand hygiene in health care settings. Geneva: World Health Organization; 2009. 
4. World Health Organization. Interim guidance: Water, sanitation, hygiene and waste management for the COVID-19 virus. World Health Organization; 2020.

5. Centres for Disease Control and Prevention. Guidelines for disinfection and sterilization in healthcare facilities, 2008 Updated May 2019. Available

from: https://www.cdc.gov/infectioncontrol/guidelines/dis infection/disinfection-methods/chemical.html [Accessed on 2020, April 3rd].

6. Wood A, Payne D. The action of three antiseptics/disinfectants against enveloped and nonenveloped viruses. J Hosp Infect 1998;38:283-95.

\section{Tables}

TABLE 1 SUMMARY OF VIRUCIDAL PROPERTIES OF ANTISEPTICS USED IN HAND HYGIENE:

\begin{tabular}{|c|c|c|c|c|c|}
\hline Antiseptics & $\begin{array}{c}\text { Typical } \\
\text { concentration }\end{array}$ & $\begin{array}{c}\text { Viruses (enveloped) e.g. } \\
\text { Coronavirus }\end{array}$ & $\begin{array}{l}\text { Viruses (non- } \\
\text { enveloped) }\end{array}$ & $\begin{array}{l}\text { Speed of } \\
\text { action }\end{array}$ & $\begin{array}{l}\text { Residual } \\
\text { activity }\end{array}$ \\
\hline Alcohol & $60-80 \%$ & Good & Moderate & Fast & No \\
\hline Chlorhexidine & $0.5-4 \%$ & Moderate & Poor & Intermediate & Yes \\
\hline lodophors & $0.5-10 \%$ & Moderate & Moderate & Intermediate & Contradictory \\
\hline
\end{tabular}

